Csirmaz László

igazságügyi szakértő

Debreceni Igazságügyi Szakértői Kamara

\title{
Társasági üzletrész értékelése házastársi vagyonmegosztási perekben Szakértői bizonyítás - Szakértői kompetencia
}

Debreceni Jogi Múhely, 2014. évi (XI. évfolyam) 3-4. szám (2014. december 30.)

\author{
„, Amikor az értékelés során \\ pereskedés felmerül, a jogi összefüggésrendszer \\ (törvények, esetjog, bírósági iránymutatások stb.) \\ alapos megértése elsőrendü fontosságú. "[1]
}

\section{Bevezetés}

A tanulmányban a szerző a Kúria Polgári Kollégium joggyakorlat-elemző csoportja „Hiányosságok a szakértői bizonyitással összefüggö egyéb kérdésekben”[2]címü témaköréhez, illetve az Alapvető Jogok Biztosának „Az igazságügyi szakértői tevékenységről" szóló jelentésében[3] feltárt problémákhoz igyekszik szakértői álláspontját kifejteni. A vagyonjogi perekben az elmúlt huszonöt évben a korábbiaktól eltérő, új típusú vagyonelemek, többek között olyan vagyoni értékü jogok jelentek meg, mint például a társasági üzletrész, mely újabb átfogó ismeretek megszerzésére késztette (volna) e vagyonelemek értékelésével foglalkozó igazságügyi szakértőket. A tanulmány házastársi vagyonjogi perekben, a címben megjelölt témakörökkel összefüggésben három Kúriai elvi határozat[4] és tizenkilenc Kúriai, illetve másodfokú bírósági eseti döntésben[5] említett igazságügyi szakértői közremüködés elemezését, valamint több vagyonjogi perben szerzett személyes szakértői részvétel tízéves tapasztalatait dolgozta fel. Praktikussági okokból e tanulmány keretei között a gazdasági jellegü jogvitákban felmerülő specifikus problémák témaköre - mint például a névhasználati jog, a márkanév, a praxisjog, goodwill, lízingek, akvizíciók stb. értékelése - nem kerül tárgyalásra, habár az itt leírásra kerülő alapfogalmak, értékdefiníciók és az említett értékelési módszerek általános érvényüek.

\section{A korszerü szakmai ismeret követelményeinek alapvető tényezői}

A Kúria Polgári Kollégiumának idézett álláspontja szerint,, a szakértői vélemény a biróság itéletét megalapozó, olyan objektiv és egzakt bizonyitási eszköz, amely általában közvetlenül és nagymértékben kihat a bíróság érdemi döntéseire." [6] és véleményem szerint a per befejezésének időpontját is jelentősen befolyásolhatja. Mindebböl következően nem lehet kétséges, hogy a szakértő szakmai felkészültsége, szakirodalmi jártassága és rendszeres szakmai továbbképzése kiemelkedő jelentőséggel bír. A tudomány aktuális állásának ismerete, illetve a korszerü szaktudás elsajátítása és alkalmazása az igazságügyi szakértő számára törvényben megfogalmazott kötelezettség. A szakirodalom bővebb ismertetése - a terjedelmi korlátok miatt - ennek az írásnak nem lehet tárgya. Az itt megfogalmazott néhány mondatban mindössze szakértő társaim érdeklődését szeretném felkelteni a téma iránt. A vállaltértékelés korszerű szakmai ismereteit - más szakterületekhez hasonlóan - az alapvető jelentőségü szakirodalmak reprezentálják. Az alapvető müvek közül egyet mindenképpen szükségesnek tartok kiemelni. A vállalatértékelés elsődlegesen Bélyácz Iván Befektetéselmélet[7] címü átfogó munkájának elsajátítását teszi szükségessé. Továbbá a tudomány aktuális állásának megfelelő korszerü szakmai ismereteket, eljárásokat és alkalmazható 
számítási módszereket az a mintegy hat-hétezer oldalnyi magyar nyelvü szakirodalom (benne e tárgyban megjelent $\mathrm{PhD}$ értekezésekkel) képviseli, mely az elmúlt 10-15 évben magyar, illetve külföldi szaktekintélyek müveiben hazánkban megjelent.

Álláspontom szerint a szakirodalom teljes körű ismerete mellett kiemelkedő jelentőséggel bír a tökepiacokon - különösen a New York-i tökepiacon[8] - forgó részvények árfolyamelemzése, azaz milyen értékmérő tényezők és fundamentumok mozgatják egy-egy cég piaci értékét. Egyúttal az árfolyamelemzés lehetőséget ad az értékelő táblázatok tesztelésére és továbbfejlesztésére is. Továbbá, a bevezető elején levő szakirodalmi idézet szerint nélkülözhetetlen e tárgykörben megjelent jogszabályi, jogirodalmi, illetve bíróságok eseti döntéseiben megjelenő állásfoglalások ismerete is. A fentiekböl láthatóan a vállalatértékelés multidiszciplináris szakterület. Meglehetősen szerteágazó, tekintélyes terjedelmü szakirodalmi, illetve jogi ismereteket, rendszeres tőkepiaci elemző munkát és nem utolsó sorban intenzív információ-technológiai alkalmazásokat igényel.

\section{Az alapfogalmak megjelenése a bíróságok eseti döntéseiben és a szakirodalmakban}

Egyértelmüen ki kell jelenteni, hogy az alapfogalmak tetszés szerinti, illetve a szakirodalmaktól eltérő egyéni értelmezése egyetlen szakterületen sem megengedett, tehát a vagyonértékelés - vállalkozásértékelés szakterületen sem lehetséges. Az elemzett jogesetek egyértelmüen rámutatnak arra, hogy a szakértők alapfogalmi ismeretei túlnyomó többségben hiányosak és a definíciók nem felelnek meg a szakirodalmi leírásoknak. Az eseti döntések konzekvenciái mindenekelőtt szükségessé teszik kiemelni azt, hogy a cég könyvszerinti értéke nem azonos a piaci értékével. A számos értékforma mindegyike más-más értékösszeget jelenít meg. Nem mindegy, hogy például könyvszerinti értéket, vagyonértéket, felszámolási értéket, likvidációs értéket, belső értéket, piaci értéket, részvényesi értéket, tulajdonosi értéket, vagy üzleti értéket kell meghatározni. A felsorolt értékformák különböző értékelési eljárás alkalmazását igényelhetik és eltérő összegü értéket határozhatnak meg. Az értékfogalmak és értékelési eljárások ismerete alapvető fontosságú, mert ennek hiánya aggályossá, megalapozatlanná és támadhatóvá teheti a szakértői véleményt. Ez pedig minden kétséget kizáróan a bíróság döntésének megnehezítését és a per elhúzódását eredményezheti.

„A perben eljárt elsöfokú bíróság a felek vagyonközösséghez tartozó kft. üzletrészek forgalmi (piaci) értékének a megállapitása végett négy igazságügyi könyvszakértöt rendelt ki, mert az elsö három szakértö - a kirendelö végzésben foglaltak ellenére - nem az üzletrészek forgalmi (piaci) értékét, hanem azok könyv szerinti értékét állapitotta meg."[9]

A szakértők több esetben hivatkoztak arra, hogy ,_[...] a forgalmi érték, a reális piaci érték, valamint a különféle értékelési fogalmak meghatározását illetöen a vonatkozó szakirodalom nem egységes. "[10]Ez a kijelentés nem felel meg a valóságnak, mert az elmúlt huszonöt évben az alapvető értékelési fogalmak a hazai és külföldi szakirodalmakban egységesen, egyértelműen és teljes körüen meghatározásra kerültek.

„Az ügyben nyolc szakértő járt el, és 12 szakvélemény készült. A szakértők eltérö módszereket alkalmaztak, hangsúlyozva: a cégérték megállapításának nincs általánosan elfogadott módszere. ”[11] Az idézett megállapítás a szakirodalmak ismeretének hiányát jelzi, ugyanis a cégértékelés módszerei és az alkalmazható számítási eljárások a szakirodalmakban többezer oldal terjedelemben egyértelműen leírásra kerültek.

Például az egyik törvényszéki eseti döntésben a bíróság megállapította, hogy [...] ,a bíróság sem 1. Szakértöi Intézet, sem a ...2. Szakértői Intézet keretében eljáró könyvszakértö szakvéleményét sem találta alkalmasnak arra, hogy azok alapján a csereszerzödésben érintett üzletrészek forgalmi értéke megállapitható legyen." [12]

$\mathrm{Az}$ eseti bírósági döntéseket elemezve látható, hogy a szakértők hiányos szakirodalmi ismereteiket elfedve azzal próbálnak érvelni , hogy a cégértékelés során a fogalmakon lehet vitatkozni,” ugyanis ,a szakirodalom nem egységes sem az értékelési eljárások, sem az 
alapvetö értékfogalmak tekintetében”. Az idézett kijelentésekkel ellentétben a fogalmakon nem érdemes vitatkozni, mert a szakirodalmak az alapvető értékfogalmakat (reális piaci érték, vállalat piaci értéke, felszámolási érték, üzleti érték, vagyonérték stb.) egyértelmüen és egybehangzóan definiálják, ezért egy szakvéleményben kizárólag ezek alkalmazhatók.

\section{1. Értékmérők - ár és érték}

Először is az ár és az érték fogalma - annak ellenére, hogy mindkettő valamilyen pénzegységben van meghatározva - nem keverendő össze. Ez a két egymástól elkülönült fogalom már az ókorban is kitüntetett megkülönböztetést érdemelt. Bár az értékelés tényekre támaszkodik, mindamellett a gazdasági érték egzakt módon nem vezethető le pusztán a tényekből. A piaci ár a piaci szereplők gazdasági megfontolásainak és egyedi preferenciáknak az eredménye, mely a kínálati és keresleti viszonyok pillanatnyi konszenzusát fejezi ki. „, $A$ csere akkor igazságos, ha egyenértékek cserélnek gazdát. A termék iránti emberi szükséglet szabja meg a termék értékét." [13]

Másodsorban egy tranzakcióban kialakult piaci ár egy pillanatnyi piaci konszenzust tükröz, mely ár kínálati túlsúly esetén lehet értéken aluli, vagy keresleti túlsúly esetén érték feletti, vagy piaci egyensúlyi helyzetben az ár megegyezik a piaci értékkel. A piaci ár kialakulása a közgazdaság csökkenő határhaszon-elméletéből vezethető le. A piaci árat tehát a kereslet és kínálat kölcsönhatásaként a piac szabályzó mechanizmusa alakítja ki, a piaci, illetve bármely egyéb értékformát pedig különböző értékelési eljárások alkalmazásával szakértő számítja ki.

\subsection{A piaci érték kitüntetett szerepe}

Az értékkategóriákat említve számos értékformát lehet felsorolni, mint például használati érték, müszaki érték, bekerülési érték, felszámolási érték, árverési érték, befektetési érték, könyvszerinti érték stb., de amikor a piaci érték fogalmához érkezünk, akkor egy merőben más, kitüntetett szerepben lévő értékformához jutottunk.

Az Alkotmánybíróság a tulajdonhoz való jog lényeges tartalmát a tulajdon értékének biztosításában, azaz az értékgaranciában[14]ragadta meg. Bármely korlátlanul forgalomképes dolgon fennálló tulajdonjog különböző okokból történő megszünésének egyenértékü ellentételezése kizárólag a piaci értéket megjelenítő összeg alapján történhet. Ugyanis a piaci értékhez a tulajdonjog elválaszthatatlanul kötődik, ahhoz annak szelvényjogai, köz és magánjogi korlátai füződnek. Továbbá szorosan kapcsolódik hozzá a tulajdonjog közvetlen tárgya, azaz az egymásközti jogviszony is. A piaci érték tehát csak és kizárólag e kettős relációban értelmezhető. Egyetlen más értékformához sem kapcsolható a tulajdonjogi teljesség, csak és kizárólag a piaci értékhez. Az egy más dolog, hogy számos értékforma kapcsolódik a tulajdonjogi triászhoz, azok értéke a piaci értékből is levezethető. A piaci érték definíciója az Európai Értékelési Szabványokban[15] világosan leírásra került, melyben minden szó különös jelentőséggel bír. Kiemelkedően fontos konzekvencia, hogy a tulajdonjog ellenértékének kizárólag a piaci érték tekinthető. A hazai értékelő gyakorlat és a jogirodalom a forgalmi érték kategóriát a piaci érték szinonimájaként értelmezi és használja.

\subsection{Legfontosabb értékformák}

Piaci (forgalmi) érték „,[...] egységes viszont a birói gyakorlat abban, hogy valamely ingatlan vagy más dolog, illetve szolgáltatás forgalmi értéke alatt azt a vételárat kell érteni, amely az adott ingatlan vagy más dolog, illetve szolgáltatás átruházása esetén a kereslet-kínálat alakulásától függöen elérhetö, illetve elérhetö lenne. "[16]

A reális (valóságos) piaci értéket csaknem egyetemesen úgy határozzák meg, mint azt a pénzbeli vagy azzal egyenértékü eszközökben kifejezett árat, amelyért a tulajdon gazdát 
cserél a vásárolni kész vevő és az eladni kész eladó között, amennyiben a felek kellő információval rendelkeznek a vonatkozó tényekkel kapcsolatban, és egyikünk sem cselekszik kényszer hatása alatt.[17]

Vállalkozás piaci értéke a müködésbe befektetett részvénytőke piaci értékének és a kölcsöntőke piaci értékének az összege, amelyhosszútávon megegyezik a várható jövőbeli pénzáramlások diszkontált értékével, vagyis az üzleti értékkel. Egy vállalat piaci értéke és diszkontált cash flow-ja között rendkívül erős korreláció van. A diszkontált pénzáramláson alapuló érték sokkal inkább megfelel a vállalat piaci értékének, mint bármely más mutatószám.[18] A tőkepiac által determinált piaci ár hosszabb időszak átlagában megegyezik a diszkontált cash flow értékével.

Üzleti érték (belső érték) a jövőbeni pénzáramlások tőkeköltséggel diszkontált jelenértékén alapuló, adott várakozások figyelembevételével, szakértő által számított érték, amely a piaci érték mozgás-centrumának tekinthető. Ebből következően nem mindig egyezik meg a piaci árral, és ezt alapvetően az információhiány okozza. (a piacnak, vagy a szakértőnek nincs kellő információja) De az eltérés csak rövidtávon létezik, hosszú távon megegyeznek.

Továbbmüködési érték a vállalatot müködésben lévő szervezetként, az alkotó elemek „élő” rendszereként tekinti és nem eszközök és kötelezettségek puszta kollekciójaként. Értéke a jövőbeni pénzáramlások tőkeköltséggel diszkontált jelenértéke.[19]

Felszámolási érték adott időpontban az eszközök egyenként meghatározott piaci értékeinek az összege csökkentve a kötelezettségek összegével és a felszámolás költségével.A felszámolási érték tehát nem más, mint a vállalkozás vagyontárgyainak értékesítéséből várható pénzbevételek és a fennálló kötelezettségek különbsége, csökkentve a felszámolás költségeivel. A felszámolási érték nem határozható meg a számviteli nyilvántartások alapján, tekintve, hogy az eszközök értékelése nem könyvszerinti, hanem aktuális piaci értéken történik. Ha az értékesítésböl befolyt összeg és az értékelés időpontja között hosszabb idő (több év) telik el, akkor a várható bevételeket diszkontálni kell az értékesítés kockázatának megfelelő rátával.

Könyvszerinti érték kissé rossz kifejezés, mivel egyáltalán semmiféle értékmércét nem képvisel. Nem is értékbecslési, hanem számviteli fogalom és csupán egy számbavételi összeg. Ennek megfelelően a mérleg eszköz, illetve forrás oldalán szereplő eszköz és kötelezettség különbségéből számítható. Könyvszerinti érték = eszközök - kötelezettségek - passzív elh. = saját töke + céltartalék. Nem értékelés eredménye, tehát különösebb szakértelem nélkül a mérleg adatokból néhány alapvető matematikai művelettel közvetlenül meghatározható.

\section{A társasági üzletrész értékdimenziói a házastársi vagyonjogi perekben}

Több esetben tapasztalható, hogy a szakértő az eszközalapú vagyonérték és a jövedelemalapú hozamérték átlagaként határozta meg egy cég piaci értékét. A szakirodalmak szerint az eszközalapú értékeléssel felszámolási, míg a hozamalapú értékeléssel továbbmüködésre alapozott piaci értéket lehet számítani. A két érték átlagolásának lehetőségét a Kúria (Legfelsőbb Bíróság) eseti döntései egyértelműen cáfolják. Az idézet szerint „a vállalkozás reális és méltányos piaci értékét a szakértőnek az ún. továbbmüködési érték és a felszámolási érték figyelembevételével, a két emlitett érték közül a magasabb értékkel egyezöen kell meghatároznia." [20]

A fentebb idézett eseti döntésekkel összhangban nem lehetséges a két értékből un. „,középérték módszerrel” kombinált értéket meghatározni. Logikailag kizárt az átlagértéket figyelembe venni, mert lehetetlen az, hogy egy céget azonos időszakban felszámoljuk és müködtetjük is. A két esemény egy időben kizárt, mert vagy felszámoljuk, vagy müködtetjük, ezért egy adott időpontban az érték vagy eszközalapú felszámolási, vagy hozamalapú piaci érték, a két érték bárminemü kombinációja nem lehetséges. 
A alábbi idézet egyértelmüen eldönti a forgalmi érték, vagy könyvszerinti érték kérdését. „ $A$ társaság tagját megillető részesedést a házastársi közös vagyon megosztása során nem a könyv szerinti, hanem a tényleges forgalmi értéken kell a vagyonmérlegbe beállitani. [...] a számviteli törvény szerint kimunkált könyv szerinti érték pedig nem is alkalmas arra, hogy akár a gazdálkodó szervezetek egymás közötti polgári jogi viszonyaiban, akár a házastársi közös vagyon megosztása során a házasfelek közötti reális és méltányos elszámolás alapjául szolgáljon, miértis annak a házastársak egymás közötti, belsö jogviszonyára történö alkalmazása nem lehet indokolt."[21](kiemelés tőlem)

\section{1. Értékelési cél - értékelési eljárások - értékelési módszerek}

Az értékelés célja lényegesen befolyásolja az értékelési folyamatot, többek között az értékelés módszerének megválasztását is. Mielőtt értékelni tudnánk egy vállalkozást, tudnunk kell, hogy milyen célból történik az értékelés. Különböző célok különböző értékhez és különböző értékelési módszerekhez vezetnek. Egy szállodát, egy atomerőmüvet, egy kenyérgyárat vagy egy tanácsadó céget nem biztos, hogy ugyanolyan módszerrel lehet értékelni.[22]

A relatív, szorzószámos értékelés tőzsdén forgó vállalkozások esetén gyakran alkalmazott értékelési eljárás. A módszer a vállalatok jellemző mutatóinak összehasonlításán alapszik. Hazai viszonyok közt a vagyonjogi perekben ritkán, kontroll módszerként csak abban az esetben alkalmazható, ha a cég jellemzőihez hasonló kínálati adatok az interneten elérhetők. Ebben az esetben a P/S (Price/Sales = Piaci (kínálati) ár/Árbevétel) szorzószám alkalmazható. Vagyonjogi perekben előforduló igen fontos kérdés, hogy melyik értékelési eljárás alkalmazható, mely módszerrel lehetséges a társasági üzletrész piaci (forgalmi) értékét legpontosabban meghatározni? Álláspontom szerint a jogirodalom és az alább hivatkozott bírósági eseti döntések a szakirodalmakkal összhangban egyértelműen megválaszolják ezt a kérdést. A bírósági eseti döntések tanúsága szerint ennek ellenére a szakértők túlnyomó többsége a szakirodalmi leírásokat figyelmen kívül hagyva mellőzi a jogi állásfoglalásokat is. Csüri Éva „A gazdasági jog egyes kérdései a házassági vagyonjogban” címü témakörrel összefüggésben kifejti, hogy „Amennyiben a társaság tovább müködik, jövedelemalapú (hozamalapú) értékelést szükséges elvégezni, amely nem más, mint a folyamatosan müködö társaság értéke. Különösen alkalmas módszer ez akkor, amikor a házassági életközösség megszakadása és a szakértöi vizsgálat között hosszabb (több éves) idötartam telik el, mivel a szükséges és általában csak tervezett adatok, ebben az esetben már beépültek a vizsgált évek mérlegbeszámolóinak tényleges adataiba, tehát már nem kell megtervezni." $[23] \mathrm{Az}$ alkalmazandó módszer tekintetében rendkívüli jelentőségü a fentebb idézett jogirodalmi hivatkozás. Ugyanis a házastársi vagyonjogi perek döntő többségének az a sajátossága, hogy a szakértői vizsgálatra több év elmúltával kerül sor. A szakirodalom ezt un. „ex-post” értékelésnek nevezi. Azaz rendelkezésre állnak az elmúlt évek számviteli adatai, melynek alapján jövedelemalapú, diszkontált cash flow módszerrel meghatározott értékelés eredményeként a lehető legpontosabb piaci érték számítható.

A Legfelsőbb Bíróság az EBH2001. 424. számú elvi határozatában és számos eseti döntésében rámutatott már arra,hogy a házastársi közös vagyon megosztása során - a társaság müködésének létszakaszában - a közös vagyon értékének a meghatározása szempontjából az életközösség megszakadásakori állapotuk és a reális (tényleges, valós, méltányos) piaci értékük az irányadó.[24]

A Pfv.II.21.078/2008/8. számú eseti döntés indokolása 2. pontjának (4) bekezdése rámutat arra, hogy; „, a továbbmüködési érték a folyamatosan müködö vállalkozás jövedelemtermelö képességének, tehát a vállalkozástól várható pénzáramlások jelenértékének (diszkontált értékének), a felszámolási érték pedig a vállalkozás nettó eszközértékének, tehát az eszközei piaci ára kötelezettségeivel csökkentett értékének felel meg." 
A fenti idézetek alapján nem lehet kétséges, hogy a piaci érték meghatározása során a tudomány aktuális állásának megfelelő és legalkalmasabb értékelési eljárás, illetve legpontosabb számítási módszer - akkor, amikor minden szükséges adat rendelkezésre áll kizárólag a jövedelemalapú, diszkontált cash flow (DCF) módszer lehet.[25]

A diszkontált cash-flow előnye, hogy független a számviteli elszámolási módszerektől, jövőorientált, nem egyetlen év adatain alapul, kezeli a vállalat olyan egyedi jellemzőit, mint a tőkeköltség, a kockázat, a szokásos és rendkívüli tételek és a vállalat tőkeáttétele, valamint számol a pénz időértékével is. Azért válhatott a DCF módszer a leggyakrabban használt eljárássá, mert ez az egyetlen olyan módszer, amely hibátlan elméleti alapokon nyugszik. A DCF módszer rugalmassága, jövőirányultsága, közgazdasági és matematikai megalapozottsága, illetve pozitív tesztelési eredményei miatt a leggyakoribb értékelési eljárás.

\subsection{Vagyonértékelés - üzletértékelés}

Elöljáróban szükséges rögzíteni, hogy cégértékelés, vállalatértékelés alatt a piaci, vagy az üzleti illetve a felszámolási érték meghatározása értendő. A vagyonértékelés vagyonérték, illetve az üzletértékelés üzleti érték fogalmak az eseti döntésekben és a gyakorlatban gyakran előfordulnak, ezért szükséges e fogalmak definiálása. A hazai szakirodalomban az üzletértékelés - mint eljárás - a vagyonértékelésnél lényegesen bővebb, alapjaiban és módszereiben más jellegü, lényegesen bonyolultabb számítások elvégzését igényli. A két eljárás lényegesen különbözik egymástól, ugyanis a vagyonértékelés statikusan, míg az üzletértékelés a tényleges müködés dinamikájában, azaz dinamikusan - az elmúlt évek fundamentumaira alapozott elörejelzési modellt építve - vizsgálja a céget. Ezért lényegesen pontosabb piaci értéket képes meghatározni, mert több év adatai alapján számításba veszi az értékváltozásokat és a pénz időértékét is. Müködési létszakaszban levő vállalkozások esetén ,,[...] az üzletértékelés során azt akarjuk megtudni, hogy a vállalatnak mennyi a piaci értéke. A vállalat megvásárlása során nem az eszközhalmazt (vagyont), hanem annak tartós jövedelemtermelö képességét szerezzük meg. Ezt a jövedelmet, pontosabban a jövöbeli pénzáramlást kell felmérni ahhoz, hogy megállapíthassuk, mennyit ér ma a vállalat. Ezt a módszert nevezzük üzletértékelésnek, az igy kapott értéket üzleti értéknek." [26]A tevékenység üzleti értéke megegyezik a várható jövőbeli pénzáramlások diszkontált értékével." [27]

Egyértelmüek a szakirodalmak és a jogi állásfoglalások abban is, hogy a piaci, illetve az üzleti értéket az eszközalapú vagyonértékelés módszerével nem lehetséges meghatározni. A vagyonértékelés módszere a vállalat folyamatos működésének és az immateriális vagyonelemek figyelmen kívül hagyása miatt nem alkalmas a humántőke közremüködése révén keletkező vállalatérték kimutatására és meghatározására.

Az értékelési célnak megfelelő módszer kiválasztása kapcsán Juhász Péter[28] megállapítja, hogy a számviteli alapú vagyonértékelés ,,nem alkalmas a vállalat piaci, vagy üzleti értékének meghatározására. A folyamatos müködési dinamizmust nem tükrözi vissza, ám jól használható fizetöképesség megállapitásánál, a vállalat megitéléséhez egyfajta kiindulási alapként, illetve pénzügyi és adóügyi összehasonlitások, jelentések készitésénél, vagy akkor, ha nincs szó a vállalati tevékenység folytatásáról (végelszámolás, felszámolás), illetve a jövöröl nagyon kevés és bizonytalan információval rendelkezünk"

Az eszköz alapú vagyonértékelés többek között azért sem alkalmas a piaci érték meghatározására, mert ,, az eszközök összessége rendszerint többet ér, mint az egyedi értékek összege. Ez a szinergia. A vállalati szinten elért szinergikus hatást azonban gyakorlatilag lehetetlen eszközszintre lebontani. ’[29]

\section{Az értékmeghatározás időpontja}

A vállalkozás értékelési időpontja vagy időpontjai az értékmeghatározás szempontjából kulcsfontosságúak, mivel a változó körülmények két időpont között az értékek drámai 
változását eredményezhetik, továbbá az értékelési dátum közvetlenül befolyásolhatja az alkalmazható értékelési eljárást és az értékeléshez rendelkezésre álló adatok mennyiségére, illetve minőségére is hatással lehet. A vállalkozás különböző létszakaszai - alapítás folyamatos müködés - felszámolás különböző időpontokhoz köthető. Az értékmeghatározás időpontja tekintetében az új Ptk. konkrétan és határozottan fogalmaz; „A közös vagyonból a házastársat megillető hányadot a vagyonközösség megszünésekor fennállt állapot és érték szerint kell megállapitani." [30]

A Legfelsőbb Bíróság EBH2001. 424. számú elvi határozatának III. pontja szerint: „A felek egymás közötti, belsö jogviszonyára irányadó Csjt. 31. \$-ának (2) és (3) bekezdése alkalmazásával összefüggésben egységes a birói gyakorlat abban, hogy a házastársi közös vagyon megosztása során a közös vagyon körének és értékének a meghatározása szempontjából az életközösség megszünésekori állapotuk és értékük az irányadó.

Csüri Éva szerint ,, a közös vagyon megosztásakori érték alapulvétele indokolt akkor, ha a tag házastárs a társaságban semmiféle személyes tevékenységet nem végez, a társaság tevékenységének a nyereséges vagy veszteséges volta e tevékenységgel szükségképpen a felek tevékenységén és mulasztásán kívül álló okokra vezethetö vissza." A vagyonközösséghez tartozó társaságbeli részesedés házastársak közötti megosztása során az adott gazdasági társaság életközösség megszünésének időpontjában fennálló cégformájának és létszakaszának az alapulvételével kell meghatározni.[31],,A helyes elszámolási időpont megválasztása különösen fontos a vagyonértékü jogok értékének a megállapitásakor. ’[32]

\section{Az értékváltozások figyelembe vétele}

A Legfelsőbb Bíróság 424. számú elvi határozata III. pontjának indokolása szerint „az olyan értékváltozást (értéknövekedést vagy értékcsökkenést) azonban amely az életközösség megszünése és a közös vagyon megosztása közötti idöszakban - a felek valamelyikének a tevékenységére vagy mulasztására vissza nem vezethetö okból - következett be, megfelelöen figyelembe kell venni." Ezért például ingatlan esetében a megosztáskori, ingó és vagyoni értékü jogok esetében a vagyonközösség megszakadásakori érték veendő figyelembe. A Kúria eseti döntése[33] szerint azt az értékváltozást azonban, amely valamelyik házastárs tevékenységének vagy mulasztásának a következménye, kizárólag ennek a házastársnak a javára vagy terhére kell elszámolni. „... helyes a másodfokú bíróságnak az az eljárása, hogy a volt házasfelek közötti elszámolás alapjaként az üzletrészek életközösség megszünésekori értékét vette figyelembe, és ezáltal az életközösség megszünése és a közös vagyon megosztása közötti idöszakban bekövetkezett értékcsökkenést az I. rendü alperes terhére értékelte."

A Legfelsőbb Bíróság fentebb idézett elvi határozatából egyértelműen következik, hogy a házastársi közös vagyon megosztása során a tag házastársat megillető értéknek a különválást követő változásai (növekedése vagy csökkenése) miatt nem érheti olyan előny, illetőleg olyan hátrány, amely többek között például a tag házastárs tevékenységére, felelőtlen gazdálkodására vagy mulasztására vezethető vissza. Az értékelési szakirodalmak ezt olyan módon definiálják, hogy a személyhez kötődő (negatív vagy pozitív) goodwill az értékelés során nem vehető figyelembe. A szakirodalmak szerint az értékelés során az vehető figyelembe, hogy a cégvezető minimum az általánosan elvárható gondosságnak megfelelően, azaz ,a rendes gazdálkodás szabályai szerint” hozza meg döntéseit. A fentiekre tekintettel Csüri Éva szerint „, az életközösség megszünésekori érték alapulvétele indokolt akkor, ha a tag házastárs a társaságban személyes tevékenységet végez, és a társaság tevékenységének a nyereséges vagy veszteséges volta e tevékenységgel szükségképpen vagy valószínüsithetöen összefüggésben áll." [34]

„A vagyonközösség megszünésétöl a közös vagyon megosztásáig terjedö időben bekövetkezett értékváltozást figyelembe kell venni, kivéve, ha az az egyik házastárs magatartásának az eredménye." [35] Amint az a 4. pontban részletesebben kifejtésre került a változó 
körülmények két időpont között az értékek drámai változását eredményezhetik. A vagyonközösség megszünésétől a közös vagyon megosztásáig terjedő időben jelentős értékváltozás bármilyen okból bekövetkezhet. Gyakori eset, hogy az értékvesztés valamely házastárs tevékenységének az eredménye, például jelentős összegü indokolatlan költségek generálása, vagy a társaság eszközeinek áron alul történő értékesítése következett be.[36] A müködési létszakaszban levő társaságok értékében bekövetkezett változások kizárólag a hozamalapú, több év konkrét számviteli adataira épülő DCF módszer alkalmazásával vehető figyelembe.

\section{Szakértői kompetencia - kirendelési gyakorlat}

A szakértelem tekintetében fontos kiemelni, hogy „Ahhoz, hogy valaki szakértö legyen, kizárólag szaktudás szükséges. A kirendelés szempontjából közömbös hogy a szakértö honnan szerezte az ismereteit, a kirendelö hatóság felelössége és egyben mérlegelési jogköre, hogy a megfelelö szakértelemmel rendelkezö személyt rendelje ki a szakvélemény elkészitésére. Egyetlen szakmai müködési kritérium az, hogy a szakkérdésekre vonatkozó válaszokat ismerje, és az általa elöadottakat, mint saját legjobb meggyözödését közölje a birósággal."[37] Többen, nagyon sokszor megfogalmazták már, - eddig eredménytelenül hogy kizárólag olyan személyek adjanak szakvéleményt, akik magas szakértelemmel, szakmai tudással rendelkeznek, olyan szakértők, akik képesek határidőn belül színvonalas szakvélemény készítésére úgy, hogy ezzel érdemben segítsék az igazságszolgáltatás hatékony müködését és a jogviták eldöntését. Az ombudsmani jelentés felhívja a figyelmet arra, hogy „[...] a szakértö kiválasztásánál a szakmai szempontok érvényesülése nem szorulhat háttérbe." [38]

Az un. „kompetencia rendelet”[39] nem egyedüli hiányosságának említhető, hogy a vagyonértékelés - benne a vállalkozásértékelés - szakterület létrehozásának igénye elkerülte a jogalkotó és a szakmai szervezetek figyelmét. Személyes tapasztalatom az, és a bevezetőben említett eseti döntések bizonyságot tesznek arról - például egy ügyben nyolc szakértő és tizenkét szakvélemény, más ügyben négy szakértő, illetve tizenkét évig tartó vagyonjogi per, vagy tárgy, marketing, gépjármü, könyvszakértők egyidejü kirendelése stb. - hogy igen kevés az olyan cégértékeléssel kapcsolatos vagyonjogi per, ahol egyetlen szakértői vélemény alapján meg lehetett volna állapítani a tényállást. A jelenlegi kirendelési gyakorlat ellentétes lehet a Pp. 177. § (1) bekezdésével, mely kimondja, hogy ,rendszerint egy szakértőt kell alkalmazni, több szakértöt csak különbözö szakkérdések felmerülése esetében lehet kirendelni." Rendkívül fontos kijelenteni, hogy a cég piaci (felszámolási, üzleti, méltányos reális, tényleges, valós stb.) értékének meghatározása nem különböző szakkérdés! Az Európai Értékelési Szabványoknak[40] és gyakorlatnak megfelelően - többek között ez egy komplex, speciális szakértelem sokaságát, széleskörü jogi és jelentős terjedelmű szakirodalmi ismereteket, rendszeres tőkepiaci elemzéseket igénylő szakterület! Azonos szakkérdésben több szakértő igénybevételével szemben az Európa Tanács Miniszteri Bizottságának az igazságszolgáltatás igénybevételét megkönnyítő eszközökről szóló jelentése[41] az „egy szakértő elvét" fogalmazza meg.

A szakértői névjegyzék hiányosságai tekintetében nem kerülhető meg annak kijelentése sem, hogy a fontos információk hiánya miatt a bíróságok nem tudnak megfelelő szakértelemmel rendelkező szakértőt keresni és kirendelni. Ugyanis néhány eset kivételével könyvszakértő kerül kirendelésre, annak ellenére, hogy nem a könyvszerinti értéket, hanem a piaci értéket kell meghatározni. És ez minden tekintetben óriási különbség! Ráadásul a BH2006. 16. szerint is egy cég piaci értékének megállapítására a könyvszakértő csak kivételes esetben alkalmas. Nem hagyható az sem figyelmen kívül, hogy a könyvszakértők képesítési követelményei (könyvvizsgálói képesítés = felsőfokú végzettség + jogi, adózási, vezetési, 140 óra + közgazdasági-pénzügyi 60 óra és számvitel-könyvvizsgálat ismeretek 314 óra összesen 
514 óra) nem írják elő a cégértékeléshez szükséges szakirodalmi ismeretek alapszintü elsajátítását sem. Az eseti döntésekben a névjegyzék hiányosságainak minden lehetséges negatív következménye jól nyomon követhető. Itt szükséges utalni arra, hogy az ombudsman az igazságügyi szakértői névjegyzékkel kapcsolatban megállapítja, hogy ,......a névjegyzék tartalma nem nyújt kellö információt a jogalkalmazó számára a megfelelö szakértö kiválasztásához, a tisztességes eljáráshoz való joggal összefüggésben visszásságot idéz elö és tart fenn."'[42]

Egy igazságügyi könyvszakértő szaktekintély idézett mértékadó véleménye nagyon jól szemlélteti az eseti döntésekben tetten érhető szakértői müködéssel kapcsolatos kompetencia körüli problémák súlyát és valódiságát. „Azzal teljesen egyetértek, hogy az igazságügyi könyvszakértök nagyobbik része nem ismeri a vállalkozások piaci érték meghatározásának módszertanát...... csak utólag derül ki, hogy még a kérdést sem értette, és ezzel az igazságszolgáltatásnak időveszteséget okoz, a szakértői testületet pedig lejáratja ...... azt sem tudta pl. hogy mi a diszkontált cash flow módszer." Felmerül a kérdés, hogy a könyvszakértőknek miért kellene ismernie a vállalkozások piaci érték-meghatározásának módszertanát és a diszkontált cash flow módszert? A vagyoni értékü jogok - mint például a társasági üzletrész - illetve az eszközök értékelésének ismerete az igazságügyi könyvszakértői tevékenység végzéséhez nem szükséges. A könyvvizsgálói tevékenységről szóló törvény[43] felsorolja a képzés főbb tanulmányi területeit és ebben nem szerepel semmilyen vállalatértékelési ismeret. A jogszabályi kötelezettségen alapuló könyvvizsgálói tevékenység felsorolása[44] és egyetlen más rendelkezés sem tartalmazza azt a komplex, szerteágazó tevékenységet, melynek eredményeként szakszerüen, a szakirodalomnak megfelelő módon meg lehet határozni egy vállalkozás piaci értékét. Amint már a bevezetőben említettem a vállalatértékelés módszereivel számított piaci érték meghatározásának bonyolult folyamatát a szakirodalom több ezer oldalon taglalja. Ha egy peres eljárásban kirendelt könyvszakértő szakirodalmi ismeretek nélkül próbálja a céget értékelni, az olyan, mintha könyvvizsgálói tevékenységét például a számviteli jogszabályok ismerete nélkül végezné.

A Kúria (Legfelsőbb Bíróság) számos eseti döntésben rámutatott arra, hogy a számviteli alapú vagyonértékelés nem alkalmas a vállalat piaci, vagy üzleti értékének meghatározására. A könyvvizsgálói tevékenységről szóló törvény 3. § (2) bekezdésének a) pontja - a jogszabályi kötelezettségen alapuló könyvvizsgálói tevékenységen kivül egyéb szakmai szolgáltatásként a bejegyzett könyvvizsgáló jogosult a gazdálkodó müködésének átvilágitására, értékelésére sem alapozhatja meg a cég piaci érték szempontú értékelését. A 3. § (2) bekezdés a) pontja egyértelmü, az átvilágítás, értékelés szavakat kizárólag együtt lehet értelmezni. Csak és kizárólag a cég müködésének átvilágításáról és müködésének számviteli szempontú értékeléséről van szó. Különböző érdekek mentén nem lehet belemagyarázni és nem kellene beleerőltetni egy vállalkozás piaci értékmeghatározására való képességet és alkalmasságot. Az meg mégiscsak abszurd lenne, ha a könyvszakértőknek szakismeret nélkül a társasági üzletrész, mint vagyoni értékü jog értékelésére a törvény jogosultságot engedélyezne. Egy vállalkozás jelentős anyagi és humán tőkebefektetést igényel. Vagyonjogi perben kirendelt szakértőnek nem lehetséges szakismeret nélkül értékelni esetenként több milliárd forint piaci értéket képviselő céget. Nem lehet az örökjáradék képletével (cégérték = éves nettó hozam / tőkésítési ráta) egy egyszerü osztással piaci értéket számítani, ahogyan az az eseti döntések túlnyomó többségében látható, mert ezzel legfeljebb csak a nagyságrend határozható meg.

A szakértői kompetencia tekintetében mindenekelött abból az eseti döntésekben egyértelmüen megfogalmazott utalásból célszerü kiindulni, mely szerint „A társaság tagját megilletö részesedést a házastársi közös vagyon megosztása során nem a könyv szerinti, hanem a tényleges forgalmi értéken kell a vagyonmérlegbe beállítani. [...] a számviteli törvény szerint kimunkált könyv szerinti érték pedig nem is alkalmas arra, hogy akár a gazdálkodó szervezetek egymás közötti polgári jogi viszonyaiban, akár a házastársi közös vagyon 
megosztása során a házasfelek közötti reális és méltányos elszámolás alapjául szolgáljon, miértis annak a házastársak egymás közötti, belsö jogviszonyára történö alkalmazása nem lehet indokolt.[45]Számos jogesetben benne van, és még sem lehet eléggé hangsúlyozni, nem könyvszerinti, hanem forgalmi értéket kell a szakértőnek meghatározni! Amennyiben pedig a cég a felszámolás létszakaszában van, akkor sem könyvszerinti, hanem felszámolási értéket (ez is az eszközök egyenként felmért piaci értékének összege) szükséges meghatározni.[46] Az alábbi idézetekben a Legfelsőbb Bíróság által a 2006. évi BH-ban 16. sz. alatt közzétett eseti határozatára hivatkozom, mely szerint „Az egyik házastársat, mint a betéti társaság tagját megillető részesedést a házastársi közös vagyon megosztása során nem a könyv szerinti, hanem a tényleges forgalmi értéken kell a vagyonmérlegbe beállitani. Ennek megállapitásához a könyvszakértö kirendelése mellett további bizonyitás lefolytatására lehet szükség”

„A könyvszakértö kirendelését ugyanis nem a társasági vagyon teljes értékének, hanem egyrészt a társasági vagyon teljes körének, másrészt az olyan vagyontárgyak könyv szerinti értékének a megállapitása teszi szükségessé, amelyek vonatkozásában a forgalmi értéken történö elszámolás nem kerülhet szóba. (Ilyennek minösülhetnek - egyebek mellett - az árukészletek, a félkész, illetve késztermékek, valamint a behajthatatlan, kétes vagy vitás követelések, illetve tartozások is.) [...] A könyvszakértői vélemény minden esetben alkalmas a társasági vagyon körének, és kivételes esetben a forgalmi értéknek a megállapítására is.

A „társasági vagyon teljes körének” megállapítására semmi szükség könyvszakértői vélemény beszerzésére, mert a mérlegen kívül tételek, mint például az immateriális eszközök nagy része - védjegyek, szabadalmak, humántőke-tudástőke, ügyféltőke, márkanevek, müködési szinergia stb. - kivételével ott van a mérlegben felsorolva. Szakismeret nélkül könyvszakértő nem is tudja az itt felsorolt immateriális javakat még beazonosítani sem, nemhogy értéküket meghatározni, mert ehhez speciális szakértelem szükséges.

Az eseti határozat fentebbi idézete szerint a könyvszakértői vélemény kivételes esetben alkalmas a (társaság) forgalmi értéknek a megállapítására is. Mely lehet ez a kivételes eset? Véleményem szerint a könyvszakértő - ugyanúgy, mint bárki más - kizárólag akkor lehet alkalmas a cég piaci értékének meghatározására, ha a tudomány aktuális állását tükröző korszerü szaktudással rendelkezik, ismeri a jelentős terjedelmü mértékadó szakirodalmakat, illetve a kapcsolódó joganyagokat, tőkepiaci elemzői gyakorlattal is rendelkezik és információ-technológiai alkalmazásokra is képes.

Nem mellözhetö azonban a valós forgalmi érték tisztázása abban az esetben, ha a társaság vagyonához jelentös értékü befektetett eszközök: immateriális javak, tárgyi eszközök (ingatlanok, müszaki berendezések, gépek, jármüvek stb.), befektetett pénzügyi eszközök (részesedések, értékpapírok stb.) és olyan egyéb vagyontárgyak is tartoznak, amelyek forgalmi értéke nyilvánvalóan lényegesen eltér a könyv szerinti értéküktöl.[47]

A jogesetekből idézett részek számos kérdés felvetését indokolják. Miért szükséges könyvszakértő által megállapítani a társasági vagyon körét? Mi lehet a köre a társasági vagyonnak és ehhez miért csak a könyvszakértő ért? Mely lehet az eseti döntésben említett kivételes eset? Ha nem könyvszerinti értéket, hanem piaci értéket kell meghatározni, akkor miért könyvszakértő kirendelése lehet indokolt? Ha vannak, márpedig nehezen képzelhető el olyan cég, amelynek ne lennének immateriális javai, akkor ezeket ki, és milyen képesítéssel fogja értékelni? Például a humántőke, a márkanév, a belépési korlátokat felállító és versenyelőnyöket biztosító jogszabályok, vagy a komparatív előnyök megléte jelentős immateriális vagyon, de mérlegen kívüli tételek, ennek ellenére fontos értékmérő tényezők.

A jelenlegi kirendelési gyakorlat[48] - minden bizonnyal kényszerüség okán - például könyv, ingatlan, tárgy, jármü stb. szakértők által a vagyonelemek egyenként felmért értékének összegzésével igyekszik a vállalkozás forgalmi értékét azonosítani. De hát ez a felszámolási értékkel azonos és nem a piaci értékkel! A szakirodalmak szerint ugyanis a vállalat piaci 
értékét kizárólag a jövedelemtermelő képessége, azaz általa a jövőben biztosított szabad pénzáram jelenértéke határozza meg. A több különböző kompetenciával rendelkező szakértők együttes kirendelésére való törekvés nem veszi figyelembe, hogy a vállalat nem egyszerü vagyonhalmaz, a vállalat sokkal több, mint a müködéséhez felhalmozott eszközök összessége. Ennek legfőbb oka az, hogy a vállalkozás jövedelemtermelő képességgel rendelkezik. Müködési létszakaszban lévő vállalatok esetében a mérlegben jelenlévő eszközök összessége - nem említve a mérlegen kívüli tételek értékét - minden esetben többet ér, mint az egyedi piaci értékek összege. A vagyonelemek egymás teljesítményét (jövedelemtermelő képességét) növelö kölcsönhatása révén, többnyire összefüggő rendszert alkotnak, ez az un. szinergiahatás, mely müködő vállalkozás esetében minden esetben gazdasági törvényszerüség. A vállalati szinten elért szinergiahatást azonban gyakorlatilag lehetetlen eszközszintre lebontani. Tehát bármilyen müködő vállalkozást kizárt eszközeire lebontva különböző szakértők által értékelni, majd a részértékek összegzésével kialakított értékre nem lehetséges azt állítani, hogy ez a cég piaci értéke, mert ez a felszámolási érték (lásd 2.3 pont felszámolási érték definícióját).

\section{Összegzés}

A szerzőnek a tanulmány megírásával és közreadásával az volt a célja, hogy az elemzett bírósági eseti döntésekben érzékelhető szakértői közremüködés hiányosságai kapcsán felhívja a téma iránt érdeklődők figyelmét a vállalatértékeléssel foglalkozó szakirodalom ismeretének jelentőségére. Az említett cél érdekében a jogesetek elemzése során szerzett tapasztalatok alapján a tanulmány mindenekelőtt törekszik közreadni az alapvető vállalatértékelési alapfogalmakat, összefoglalni a szakirodalmakban általánosan elfogadott és alkalmazott legfontosabb értékformák definícióit és vázolni az alkalmazható értékelési módszereket. A tanulmány elméleti hátterét egyrészt az elmúlt tíz év során különböző egyetemeken szerzett vagyonértékelői ismeretek, másrészt vagyonjogi perekben és magánmegbízás alapján készült vállalatértékelési szakvélemények elkészítésének tapasztalatai adják.

A tanulmány azzal az igénnyel készült, hogy hasznos információkkal szolgáljon a társasági üzletrész, mint vagyoni értékü jog értékelésével foglalkozó szakértők számára, valamint segítséget nyújtson a vagyonjogi pereket tárgyaló bírák részére is. Az áttekintett jogesetek az itt leírt konzekvenciákon túl még számos - itt nem említett - probléma elemzését és megvitatását igényelné, melyre a téma iránt érdeklődők számára mindenképpen érdemes lenne valamilyen formában lehetőséget és alkalmat teremteni.

A gazdasági társaságbeli részesedés a társaság bármely létszakában jelentős vagyoni értéket képvisel és ennek a vagyoni értékű jognak az értékmeghatározása a szakértő speciális szakértelmét igényli. Az egyes szakterületeken müködő igazságügyi szakértők megítélése az általuk végzett munka minőségén keresztül történik, ezért egy-egy vagyonjogi perben a magas színvonalú, szakirodalomra alapozott, szakszerü szakértői közremüködés kiemelkedő jelentőségü. A tanulmány az eseti döntésekben előforduló értékformákat gyüjtötte össze, mely legfontosabb fogalmak minden mértékadó szakirodalomban egységesen definiálásra kerültek. Ha ezeket minden szakértő ebben a formában értelmezné és használná, akkor nem fordulhatna elö az, hogy „az elsö három szakértő - a kirendelö végzésben foglaltak ellenére - nem az üzletrészek forgalmi (piaci) értékét, hanem azok könyv szerinti értékét állapitotta meg."

Az értékelési módszer helyes megválasztása tekintetében felmerült igen fontos kérdésre hogy melyik értékelési eljárással lehet a vagyonjogi perekben a társasági üzletrész piaci értékét legpontosabban meghatározni - a válasz egyértelmüen csakis az lehet, hogy müködési létszakaszban lévő vállalkozás esetében, hazai viszonylatban, ha a szükséges adatok (az értékelés időpontját megelőző három-öt év számviteli adatai kellenek) rendelkezésre állnak, akkor kizárólag a jövedelemalapú, diszkontált cash flow módszer alkalmas. Szakirodalmi 
ismeret nélkül az eljárás gyakorlati alkalmazása nem lehetséges, és az is bizonyos, hogy annak a hat-hétezer oldalnyi ismeretanyagnak az elsajátítása azonban hosszú évek szisztematikus munkáját követeli meg.

A kompetencia vonatkozásában azt szükséges kiemelni, hogy a vállalat értékformáinak legyen az például piaci, felszámolási vagy bármely érték - meghatározása, illetve „a társasági vagyon teljes körének megállapítása" nem különböző szakkérdés. Mivel a müködő vállalkozás alkotó elemeit összefüggő, egymással kölcsönhatásban lévő egységként kell értelmezni, ezért azt értékelni is annak összességében kell, az eszközök „darabonkénti” értékeinek összegével piaci értéket nem lehet meghatározni. A legösszetettebb feladatot a vállalkozás piaci értékének meghatározása jelenti, a felszámolási érték kiszámítása lényegesen egyszerübb értékelési eljárásokkal lehetséges.,„[...] érdemi döntésre kiható eljárási szabályt sért a bíróság, ha többirányú speciális szakismeretet igénylö jelentös tény megállapitásához vagy megitéléséhez olyan szakértöt vesz igénybe, aki képesitésénél fogva csak az egyik szakterületen rendelkezik megfelelö szakismerettel'"[49]

Amint az 1. pontban említésre került, a vállalatértékelés multidiszciplináris, speciális szakismeretet igénylő szakterület. Ez azt is jelenti, - és az eseti döntések elemzése alátámasztja ezt a véleményt - hogy a könyvszakértő számviteli ismeretei nem elégségesek a vállalkozás piaci, vagy felszámolási értékének kiszámításához. Továbbá az is bizonyos, hogy a több tudományterületet érintő, speciális ismereteket igénylő képzettséget nem lehetséges egyetlen szervezett oktatási forma által sem elsajátítani. Nehezen képzelhető el az, hogy bármilyen szervezett formában zajló képzés cégértékeléssel kapcsolatos tananyaga például a vagyonmegosztási perekkel összefüggő esetjog, vagy elvi határozatok ismeretét írná elő. Az információs társadalmakban a korszerü, multidiszciplináris szaktudáshoz való gyors hozzájutás kizárólag az infokommunikációs eszközökkel biztosítható. Ezen eszközök fejlesztése révén folyamatosan nő az egyéni úton (autodidakta módon) megszerezhető ismeret, illetve információ mennyisége, és javul annak formai és tartalmi minősége is. Nem lehet kétséges, hogy napjainkra az internet a legnagyobb és leghatékonyabb tudásbázissá vált a világon.

Nem vitatható az sem, ahhoz hogy valaki igazságügyi szakértő legyen, a lehető legmagasabb szintü szaktudással kell rendelkeznie, illetve a lehető legfrissebb ismeretek gyors elsajátításának képességével és lehetőségével is rendelkeznie kell. A polgári perrendtartás magyarázata szerint , ,[...] Ahhoz, hogy valaki szakértö legyen, kizárólag szaktudás szükséges. Az, hogy a szakértö honnan szerezte az ismereteit, közömbös. Egyetlen szakmai müködési kritérium az, hogy a szakkérdésekre vonatkozó válaszokat ismerje. ’[50] A jelenlegi képesítési feltételeket előíró miniszteri rendelet az előzőekben kifejtettektől fényévnyi távolságra leledzik, előidézve ezzel mindazt, amit az ombudsmani jelentés a szakértői kompetenciák, képzettségi feltételek és a névjegyzék tartalmát illetően megjegyzett.

Az pedig, hogy a jelenlegi igazságügyi névjegyzékben nem szerepelnek azok a szakértők, akik a vállalatértékelés területén megfelelö komplex szakértelemmel és gyakorlati tapasztalatokkal (azaz kompetenciával) rendelkeznek - az elemzett jogesetekböl láthatóan - a bíróság döntését nehezíti meg és a perek elhúzódását idézheti elő. Az ombudsmani jelentés a vizsgálat érdeme tekintetében megállapítja, hogy „, az eljárások elhúzódását sok esetben a nem megfelelö szakértö kiválasztása, esetleg a kompetens szakértő hiánya okozza/okozhatja. "[51]Továbbá, az OBH elnökének felkérésére készült Pécsi Törvényszék elnökének összefoglaló jelentése szerint „az igazságügyi szakértői véleményadás jogszabályi környezete és müködésének gyakorlata nem segíti az igazságszolgáltatás időszerü müködését, az nagymértékben hozzájárul az ügyek elhúzódásához."

Az igazságügyi szakértői névjegyzék tekintetében összegzésként azt szükséges kiemelni, hogy a névjegyzékben az összes olyan információ rögzítésére szükség lenne, amelyek a kirendelő szerveket maximálisan tájékoztatják és segítik egy-egy ügyben a legalkalmasabb és 
legképzettebb szakértő kiválasztásában. A polgári perrendtartási szabályok minden esetben megkövetelik a szakértői vélemények fogyatékosságainak teljes körü kiküszöbölését és az egzakt szakértői válaszok rendelkezésre állását. Mindezekből adódóan a komplex, speciális ismereteket megkövetelő szakértői bizonyítás során szükségszerüen előtérbe kerülhetnek azok a szakvélemények, melyek világos módszertan mellett, egzakt, szakirodalomra alapozott és kategorikus véleményt adnak. Az ma már minden érintett fél (kamara, bíróságok, ügyészségek, kormányhivatalok, szakértők stb.) előtt ismeretes, hogy a megfelelö szakértelemmel rendelkező szakértő kiválasztásához a jelenlegi szakértő névjegyzék információ tartalma minden szempontból alkalmatlan. A jelenlegi állapot pedig adatvédelmi és személyiségjogi védelemmel aligha magyarázható és nem indokolható, hiszen a szakértőnek is az lenne az érdeke, hogy szaktudásáról minél több releváns adat megismerhető legyen. A névjegyzék hiányosságainak taglalása túlmutatna e tanulmány keretein, de azt mindenképpen szükséges megjegyezni, hogy legalább például az iskolai végzettség, a képesítések, a személyi minősítések, a szakterületen belül különösen gyakorlott részterületek feltüntetésére mindenképpen szükséges lenne.

A Kúria Polgári Kollégium joggyakorlat-elemző csoportja a bevezetőben említett véleményében megállapította, hogy az előforduló hatályon kívül helyezési okok között aránytalanul magas a szakértői bizonyítással összefüggő esetek száma. Az alapvető jogok biztosának vizsgálata több esetben megállapította és nyomatékosan felhívta a figyelmet arra, hogy egyes szakértői tevékenység képesítési feltételeinek jogi szabályozása a jogbiztonság követelményének érvényesülését veszélyezteti. Az elmúlt hét évben több jogszabály módosítási javaslatot juttattam el a jogalkotónak (KIM), de többségüket a minisztérium válaszra sem méltatta. Többek között javasoltam, hogy a polgári perrendtartásról szóló törvény 177. § (1) bekezdésével összhangban, illetve az európai gyakorlatnak megfelelően a vagyonértékeléssel, azaz a különböző vagyonelemek értékmeghatározásával kapcsolatos összes igazságügyi szakértői tevékenységet (ingatlan, termőföld, gép- berendezés- eszköz, cégértékelés, vagyonértékü jogok stb.) és kompetenciát a jogalkotó külön szakterületként „Igazságügyi vagyonértékelés” címszó alatt átfogóan, és egységesen szabályozza. Több szakértő társammal egyetemben, számtalan alkalommal kifogásoltuk az ún. „kompetencia rendeletet", mely gátolja az igazságügyi szakértés pozitív megítélését és sokszori módosítása (eddig 229 módosítás) használatát egyre nehezebbé tette. A képesítést elöíró jelenlegi jogszabály egyes szakterületeken - az ombudsmani jelentés megállapításai szerint is - az utánpótlást jelentő fiatal, felkészült, szakirányú diplomákkal rendelkező szakértőket zárt ki egyes szakterületekről, ugyanakkor kevésbé felkészült személyek számára biztosított igazságügyi szakértői jogosultságokat.

Az alapvető jogok biztosának jelentéséből idézett részletek, illetve a Kúria Polgári Kollégium fentiekben idézett összefoglaló véleménye mindenképpen arra ösztönözheti az ügyben érintett szervezeteket - mindenekelőtt a Magyar Igazságügyi Szakértői Kamarát - és az ügy iránt elkötelezett szakértőket, hogy a fentiekben taglalt szakértői működés szakmai és jogszabályi hiányosságait előidéző okok megszüntetésére mielőbb hatékony javaslatokat dolgozzanak ki és juttassanak el a jogalkotó számára. Az ombudsmani jelentés szerint „az igazságügyi szakértői tevékenység átfogó, komplex szemléletmódú vizsgálata és annak megújitása szükséges, többek között abból a célból, hogy a birósági eljárások idöszerü befejezése biztositható legyen. "[52]

Bizonyos, hogy a vagyonjogi viszonyok új Kódexben történő szabályozása megköveteli az igazságügyi szakértői tevékenység szabályozásának megújítását is. Az sem lehet kétséges, hogy az igazságügyi szakértői tevékenység átfogó, komplex szemléletü, újraszabályozása növelheti a jogbiztonságot, erősítheti az igazságügyi szakértői tevékenységbe vetett meginogni látszó közbizalmat és nem utolsó sorban megkönnyítené a jogalkalmazók és 
jogkereső állampolgárok eligazodását is. Ezúttal talán lehet bízni abban, hogy a jogszabályi környezet megújítási folyamatából a szakterület felkészült képviselői nem maradnak ki.

\section{Assessing of company shares in marital property sharing lawsuits - Summary}

New types of assets has appeared in property lawsuits in the past 25 years, such as company shares (one of the most important kind of valuable rights). This fact made forensic experts who deal with evaluation of these assets - to obtain additional comprehensive knowledge. The Kuria quoted that "the expert opinion is an underlying proof for the court judgment, an objective and precise means of proof, which usually affects directly the decisions of the court," and I think the date of the completion of the trial can be affected significantly.

The author of the study and writing of the addition was designed to court pointed out weaknesses in the analyzed case by case decisions perceived peer involvement draws the attention of the interested public on the company's assessment of literature on the importance of knowledge. To that aim the light of the experience gained from the analysis of the case law, above all, the study seeks to publish the company's fundamental valuation basic concepts summarize the literature on the same value in generally accepted and applied definitions and outline the applicable assessment methods. It is certain that the regulation of property relations in the new Code requires the renewal of judicial regulation of professional activity as well.

[1] Shannon Pratt: Üzletértékelés Kossuth Könyvkiadó 1992. 366.

[2] Kúria Polgári Kollégium: Összefoglaló vélemény A perorvoslati bíróságok hatályon kívül helyezési gyakorlata IX/4. alfejezet 52-53.

[3] Alapvető Jogok Biztosa: AJB-7766/2013. számú jelentés.

[4] www.birosag7.webgrafika.hu/elvi-birosagi-hatarozatok (letöltve 2014. március)

[5] www.birosag.hu/ugyfelkapcsolati-portal/anonim-hatarozatok-tara (letöltve 2014. március)

[6] Kúria Polgári Kollégium: Összefoglaló vélemény A perorvoslati bíróságok hatályon kívül helyezési gyakorlata IX/4. alfejezet 52.

[7] Bélyácz Iván: Befektetés-elmélet. Pécsi Tudományegyetem Kiadó (2001)

[8] www.nyse.com New York Stock Exchange (NYSE)

[9] Kúria Pfv.II.21.267/2008/9.

[10] Kúria Pfv.II.21.820/2007/7.

[11] BH2007. 421.

[12] Somogy Megyei Bíróság (anonim ügyszám).

[13] Arisztotelész: Nikomakhoszi etika Helikon Kiadó 1971. (129. oldal)

[14] 64/1993. (XII. 22.) számú AB határozat.

[15] TEGoVA: European Valuation Standards 2003 FÜTI OMEGA Kiadványozási és Oktatási Kft.2003 S4.06 - S4.30. 28-34.

[16] EBH2001. 424., Pfv. II. 22. 969/1997/2., Pf. II. 25.352/2001/5., BH 1999/9/408.

[17] Shannon Pratt: Üzletértékelés, 12.

[18] T. Copeland - T. Koller - J. Murrin: Vállalatértékelés Budapest Panem Könyvkiadó Kft. 1999. 61., 68.

[19] Bélyácz I. A vállalati pénzügyek alapjai Aula Kiadó Kft. 2007. 119.

[20] Kúria (L.B) Pf.II.25.352/2001/5.; Pfv.II.21.078/2008/8. Pfv. II.20.238/2010/6.

[21] EBH2001. 424., BH2006. 16. 
[22] T. Copeland - T. Koller - J. Murrin: Vállalatértékelés 27.

[23] Nagy Andrea Az üzletrészek forgalmi értékének meghatározása a bírói gyakorlatban a házastársi közös vagyon megosztása körében. Sectio Juridica et Politica, Miskolc, Tomus XXVI/2. (2008), 633.

[24] Kúria (Legfelsőbb Bíróság) Pfv.II.20.529/2010/11.; Pfv.II.22.191/2009/4.; Pfv.II.20.238/2010/6.

[25] Kúria (L.B) Pf.II.25.352/2001/5.; Pfv.II.21.078/2008/8.; Pfv.II.21.820/2007/7.

[26] BKE Pénzügyi Intézetének Oktatói 1998. 438.

[27] T. Copeland - T. Koller - J. Murrin: Vállalatértékelés 168.

[28] Juhász Péter „Az üzleti és könyv szerinti érték eltérésének magyarázata - Vállalatok mérlegen kívüli tételeinek értékelési problémái” címü PhD értekezés 11-13.

[29] U.o. 21.

[30] Ptk. 4:60. § (1) bek.

[31] Kúria (Legfelsőbb Bíróság Pfv.II.22.191/2009/4.

[32] Debreceni Ítélőtábla Pf. III. 20.538/2008/7.

[33] Kúria (L.B) Pfv.II.22.191/2009/4. számú.

[34] Csüri Éva: Értékpapírok és társasági részesedések a házassági vagyonjogban HVG-Orac Kft. Kiadó 2000. 340. 2.3 pont (4) bekezdés.

[35] Ptk. 4:60. § (1) bekezdés.

[36] Kúria (L.B) Pfv.II.22.191/2009/4.

[37] Németh János - Kiss Daisy (szerk.) A polgári perrendtartás magyarázata Complex Kiadó Kft. Budapest 20071000.

[38] Alapvető Jogok Biztosa: AJB-7766/2013. számú jelentés 21.

[39] 9/2006. (II. 27.) IM rendelet.

[40] TEGoVA European Valuation Standards 2003 189-208.

[41] Európa Tanács Miniszteri BizottságR (81) 7. számú Ajánlás az igazságszolgáltatás igénybevételét megkönnyítő eszközökröl 7. elv.

[42] AJB. 7766/2013. számú jelentés 19.

[43] 2007. évi LXXV törvény 90. §-a.

[44] U.o. 3. §-a.

[45] EBH2001. 424.

[46] BH 2007/373.,Pfv.II.22.276/2006/4.

[47] Csüri Éva: Cégvagyon - Házastársi vagyon, Hírtőzsde Holding. Cégvezetés 2003. évi 10. szám.

[48] BH2007. 421., BH2006. 16.

[49] BH2006. 161.

[50] A polgári perrendtartás magyarázata 1000.

[51] Az Alapvető Jogok Biztosának Jelentése az AJB-7766/2013. számú ügyben 2.

[52] Az Alapvető jogok Biztosának Jelentése az AJB-7766/2013. számú ügyben 16. 